\title{
Product-Line Extensions and Pricing Strategies of Brand-Name Drugs Facing Patent Expiration
}

\author{
SONG HEE HONG, PhD; MARVIN D. SHEPHERD, PhD; DAVID SCOONES, PhD; and THOMAS T.H. WAN, PhD
}

\begin{abstract}
OBJECTIVE: This study proposed an alternative to brand loyalty as the explanation for the continued price rigidity of patent-expired brand-name prescription drugs despite the increase in market entry of generic drugs facilitated by the 1984 Drug Price Competition and Patent Term Restoration Act. Study hypotheses were to test (1) whether market entries of new-product extensions are associated with market success of original brand-name drugs before generic drug entry, and (2) whether original brand-name drugs exhibit price rigidity to generic entry only when they are extended.

METHODS: The design is a retrospective follow-up study for the prescription drug brands that lost their patents between 1987 and 1992. The drug brands were limited to nonantibiotic, orally administered drugs containing only 1 active pharmaceutical ingredient. Information on patent expiration, entry of a product extension, and market success were determined from the U.S. Food and Drug Administration's Orange Book, First DataBank, and American Druggist, respectively. Market success was defined as whether an original drug brand was listed in the top 100 prescriptions most frequently dispensed before facing generic entry. Product-line extension was defined as the appearance of another product that a company introduces within the same market after its existing product. Drug prices were average wholesale prices from the Drug Topics Red Book. The relationship between product-line extension and market success was examined using a logistic regression analysis. The price rigidity to entry was tested using a panel regression analysis.
\end{abstract}

RESULTS: A total of 27 drug brands lost their patents between 1987 and 1992. Drug brands that achieved market success were 16 times more likely to be extended than were those that did not $(\mathrm{OR}=16,95 \%$ confidence interval, 2.12-120.65). The price rigidity to entry existed in drug brands with extensions $(\beta=2.65 \%, P<0.033)$, but not in those brands without extensions $(\beta=-2.40 \%, P<0.001)$.

CONCLUSION: This study provided some support for the alternative explanation to brand loyalty that a new product-line extension introduced for an original brand helps the original price be rigid despite the entry of generic drugs facilitated by the 1984 Drug Price Competition and Patent Term Restoration Act.

Keywords: Brand-name prescription drugs, Generic drug competition, Price rigidity to entry, Line extension

J Manag Care Pharm. 2005;11(9):746-54

Note: An editorial on the subject of this article appears on pages 772-73 of this issue.

Authors

SONG HEE HONG, PhD, is an assistant professor, Division of Pharmaceutical Evaluation and Policy, University of Arkansas for Medical Sciences, Little Rock; MARVIN D. SHEPHERD, PhD, is a professor, Department of Pharmacy Administration, University of Texas at Austin; DAVID SCOONES, PhD, is an associate professor, Department of Economics, University of Victoria, British Columbia, Canada; THOMAS T.H. WAN, PhD, is a professor, College of Health and Public Affairs, University of Central Florida, Orlando.

AUTHOR CORRESPONDENCE: Song Hee Hong, Ph.D., Assistant Professor, Division of Pharmaceutical Evaluation and Policy, University of Arkansas for Medical Sciences, 4301 W. Markham St., Slot 422-4, Little Rock, AR 72205. Tel: (501) 686-6298; Fax: (501)296-1168. E-mail: hongsonghee@uams.edu Copyright $\odot$ 2005, Academy of Managed Care Pharmacy. All rights reserved.
I $\mathrm{n}$ recent years, expenditures on prescription drugs rose more rapidly than any other component of health care. In 2001, the cost of prescription drugs was $15.7 \%$ higher than in 2000. ${ }^{1}$ In addition, prescription drug costs now represent a larger percentage of the total health care costs. In 2002, national retail spending on prescription drugs comprised roughly $10.5 \%$ of total spending on health care, an $81 \%$ increase from $5.8 \%$ of total spending in 1993 . $^{2}$

The Kaiser Family Foundation attributed $42 \%$ of the spending increase experienced from 1997 to 2002 to increased utilization, $34 \%$ to shifts in the mix of drugs used (from older, less-expensive drugs to newer, higher-cost drugs), and $25 \%$ to price inflation of existing drugs. ${ }^{3}$ Shifting customers to newer, higher-cost drugs is controversial because newer drugs are not always innovative. In fact, only 15\% of the 1,035 new drugs approved by the U.S. Food and Drug Administration (FDA) from 1989 through 2000 were innovative drugs. ${ }^{4}$

The pricing strategy of brand-name drugs going off patent is equally controversial. Historically, brand-name drugs have been able to maintain high prices even after patent expiration. ${ }^{5-7}$ Prior to 1984 , the price rigidity of the patent-expired brand-name drugs was explained by barriers to entry. According to the 1962 Kefauver-Harris Drug Amendments, both pioneer drugs and their generic versions had to document proof of drug safety and efficacy; as a result, few generic drugs were able to enter the market.

In the wake of public outcry over high drug prices and rising drug expenditures, the 1984 Drug Price Competition and Patent Term Restoration Act was enacted to pave the way for easier market entry for generic drugs. ${ }^{8}$ The act created the vehicle of an Abbreviated New Drug Approval (ANDA) to reduce the burden of proof of drug safety and efficacy for generic drugs. An ANDA requires only that a generic drug demonstrate bioequivalence to a drug already approved. ${ }^{9}$

Since generic drugs are very similar to formulations already approved, this reduction of regulatory barriers to entry should have promoted price rivalry with little threat to consumer safety. However, although the number of generic entries has increased, empirical studies report no evidence of such price rivalry; rather, price increases of brand-name drugs were maintained or, in some cases, went up upon expiration of their patent. ${ }^{5,10}$ For example, the average rate of price increases for the 18 products that faced generic competition from 1983 to 1987 was $8.4 \%$ per year before the generic drug entry; however, in the postentry period, only 2 of the 18 products experienced a statistically significant moderation in the rate of price increase ${ }^{10}$ This price rigidity of patent-expired brand-name drugs is well recognized, 
but the phenomenon has puzzled economists and policy makers who had expected price rivalry from the eased entry of generic competitors following the 1984 law.

Many studies trace price rigidity of patent-expired drugs to consumers' price insensitivity toward brand-name drugs, ${ }^{5,6,10,11}$ When a market is segmented between the price-sensitive consumers who adopt the generic and the price-insensitive consumers who continue to use the brand-name drug, the brand-name drug firm can raise its price optimally to its captive or price-insensitive clients and simply ignore the price-sensitive business siphoned off by its generic competitors. ${ }^{7}$ In fact, prescription drug markets have many characteristics that would predict price insensitivity. For example, physicians make prescribing decisions on drug therapy for consumers. Few physicians can inform themselves fully about a range of available alternatives because of the complex array of drugs. Third-party payment reduces drug prices dramatically for consumers by requiring fixed-dollar copayments that may be a small fraction of the total price of the drug. The combination of these factors makes drug markets less price sensitive. ${ }^{12}$

However, the brand-loyalty theory is losing ground as market conditions conducive to brand loyalty fade dramatically in the 20 years since the 1984 law. The number of generic entries for patent-expiring drugs has increased substantially. Cook reported that for 13 major drugs with patents expiring between 1990 and 1993, 11 experienced generic entry within 2 months of patent expiration. ${ }^{13}$ In contrast, only 2 of the top 13 drugs with patents expiring between 1976 and 1982 had generic entry within 1 year of patent expiration. Managed care organizations like health maintenance organizations and pharmacy benefit managers have implemented cost-containing measures, and, once a brand-name drug faces generic competition, generic versions are substituted for the brand-name drug $92 \%$ of the time..$^{14}$ A question then arises as to how brand-name drugs are able to maintain high prices despite losing the majority of the market to generic versions.

This study aims to answer that question by examining the 10 years following the 1984 law because this time period is unique in that a cost-sensitive market environment began to form. During this transition, not only did more generic drugs erode market shares of their brand-name drug counterparts but also more product-line extensions began to enter the pharmaceutical market. Furthermore, although many studies have examined price rigidity in this transition period, they did not control for whether or not brand-name drugs were extended. ${ }^{7,10}$

This study proposes an alternative explanation for the price rigidity theory. It begins with a presumption that a brand-name drug faces price competition from generic versions once its patent expires. It also recognizes that drug firms compete not only on price but also in new-drug development for maximum profits. The brand owner, aiming to keep its market success protected from price competition, extends the original drug with a new modification. The extension is closely related to the original product and has the market exclusivity that the original is about to lose. The brand owner then sustains the price of the original product, despite the entry of its generic versions, to help increase its new extension's demand. Therefore, the original brandname drug, when extended, shows the price rigidity to entry.

A line extension is a variation of an existing product. ${ }^{15}$ The variation can be a new formulation of an existing product or a new modification of an existing molecular entity. The general marketing literature documents many types of line extensions, such as novel versus older line extensions (first time vs. repeated introduction of a continuous-release dosage form), nonbranded versus branded (Tide bath soap vs. Tide Irish Spring bath soap), slot-filler versus new-attribute expansions (e.g., Tide + bath soap vs. Life Savers + cough liquid) and cobranded versus selfbranded ingredient (e.g., Life Savers with Dayquil vs. Life Savers with ClearCold). ${ }^{16}$

Line extensions, although few in number prior to the 1984 law, are now prevalent in the pharmaceutical drug industry. Following the 1984 law, generic drugs began to erode market shares of brand-name drugs. To continue the success of patentexpiring brand-name drugs, the firms had to introduce new extensions and then shift demand from original brands to their new extensions. Peny and Young reported in 1996 that a majority of drugs facing the loss of patent protection had already been extended one way or another. ${ }^{17}$ Grabowski and Vernon (1992) noted strong market positions held by new extensions and said that an important strategy is to shift consumers from the original formulation, subject to severe price competition, to a new formulation, insulated from price competition..$^{10}$ The National Institute for Health Care Management reported that as many as 674 (65\%) of 1,035 new drugs approved by the FDA from 1989 through 2000 were modified versions of existing drugs; only 361 (35\%) were of new molecular entities. ${ }^{18}$

Quite a few studies in the economic literature for industries other than pharmaceuticals have examined how a line extension affects rivalry. According to Schmalensee ${ }^{10}$ and Judd, ${ }^{20}$ a line extension may preempt the market entry of a rival. Kadiyali et al. ${ }^{21}$ reported that a line extension helps rival firms achieve price coordination. Kadiyali et al. ${ }^{15}$ later examined how a line extension (Yoplait Lite yogurt) changed the price rivalry between Dannon and Yoplait in the dairy market. After the introduction of Yoplait Lite, the price of Yoplait became less sensitive to changes in the price of its rival product (Dannon) than it was before the introduction of Yoplait Lite.

The present study seeks to provide empirical evidence for the alternative explanation, that the original brand-name drug, when extended, exhibits price rigidity to entry. The specific objectives are ( $\mathrm{Hl}$ ) to test whether market entries of new extensions are associated with market successes of original brand-name drugs and (H2) to determine whether original brand-name drugs exhibit price rigidity to generic entry only 
when they are extended. The results of this study will help explain why modified versions of existing drugs have frequently entered the market following the 1984 law and why postentry prices of brand-name drugs increase at preentry rates despite large shares of the markets being lost to their generic competitors.

\section{Methods}

\section{Drug Brand Selection and Study Design}

We identified a set of brand-name prescription drugs that lost its patent protection between 1987 and 1992. This set of drug brands was followed for prices and line extensions for the period of 1985 through 1995. The "brand-name" drug brand was limited to orally administered, nonantibiotic, single-ingredient pharmaceuticals. Antibiotic drugs were excluded because they have not been shown to have price rigidity to entry that requires alternative explanations to brand loyalty. ${ }^{6}$

For the first study objective, data were collected on whether brand-name drugs attained market success before generic entry as well as whether they were extended. For the second objective, annual time series of price data were collected for each drug brand selected. The time series spans the same period of 1985 through 1995 for all the drug brands selected. Using the timeseries data, the price rigidity to entry was examined first for all drug brands combined and then for each category of drug brand, i.e., brands with new extensions and brands with no new extensions.

\section{Data Sources}

Orally administered, nonantibiotic, single-pharmaceuticalingredient brand-name drugs were identified from First DataBank. ${ }^{22}$ The FDA Orange Book was used to identify the year in which each drug brand lost patent protection. ${ }^{23}$ The information on the loss of patent protection was double-checked using a series of annual publications of the Drug Topics Red Book. ${ }^{24}$ The Drug Topics Red Book lists all drug products sold in the market in a given year; the first appearance of a generic version in a specific (year) issue of Red Book indicates that a brand-name drug has lost its patent protection and thus faced generic competitors in that year.

A line extension was defined as another product that a company introduced within the same market after its existing product. The market definition was based on a therapeutic categorical system of 3-digit Hierarchical Ingredient Codes (HICs). ${ }^{25}$ The HICs classify drugs into distinct categories such as antihypertensive drugs and nonsteroidal antiinflammatory drugs. A line extension is defined in this study as either a new formulation or a new molecular entity within the same HIC drug category. If the new formulation was a tablet or a capsule of an existing product, it was not defined as a line extension.

Market success of original drug brands was identified from the top 200 prescription drugs most frequently dispensed through the U.S. community pharmacy. American Druggist publishes this information annually. ${ }^{26}$ A market success was defined as a drug-brand presence in the top 100 drug list 1 year prior to the entry of its generic competitors.

Drug price data were collected from the Drug Topics Red Book, which lists average wholesale prices (AWPs) for drug products every year. Although AWPs are list prices and not transaction prices, they are related to transaction prices. AWPs are important because they are the customary basis for reimbursing pharmacies for drug dispensing by third-party payers. ${ }^{27}$

A brand-name drug has multiple National Drug Codes (NDCs) determined by package size, dosage form, and strength. A representative NDC was selected for each brand-name drug based on its continuous availability throughout the time period, and its annual series of AWPs were obtained from the 19851995 issues of the Drug Topics Red Book. The AWPs were deflated using gross domestic product (implicit price indices) for the same years. ${ }^{28}$

\section{Data Analysis}

Two research hypotheses were tested by following an endogenous switching selection model (Maddala, 1983). ${ }^{29}$ In other words, different price equations were specified depending on whether brands were extended or not.

(1) dichotomous switching equation:

$\mathrm{I}_{i}{ }^{*}($ unobserved $)=\mathrm{Z}_{i} \cdot \gamma+\varepsilon_{i}$

$\mathrm{I}_{i}=1\left(\right.$ extension $_{i}=$ yes $)$ if $\mathrm{I}_{i}{ }^{*}>0$

$\mathrm{I}_{i}=0\left(\right.$ extension $_{i}=$ no $)$ else

(2) price equation:

$p_{i}^{E}=X_{i}^{E} \cdot \beta^{E}+u_{i}^{E}$ iff $I_{i}=1$ (for brands that are extended).

$p_{i}^{E}=X_{i}^{N E} \cdot \beta^{\top \amalg}+\mathcal{U}_{i}^{N E}$ iff $I_{i}=0$ (for brands that are not extended).

The dichotomous switching equation (1) was specified as follows: $\operatorname{Prob}\left(\mathrm{I}_{i}=1\right)=\phi\left(\beta_{0}+\beta_{1}\right.$ top $\left.100_{i}\right)$. The index variable, Ii, indicates whether or not a line extension has been introduced for original brand $i$. The variable, "top $100_{i}$," as a proxy for the market success of original brand $i$, indicates whether or not the original brand ranked in the top 100 prescriptions most frequently dispensed 1 year prior to entry. Regression parameters were estimated using SAS logistic regression, which yielded an odds ratio of extension in brands that had ranked in the top 100 compared with those that had not ranked. Wald chi-square test statistics were used for hypotheses testing at $\alpha=.05$.

Ordinary least square estimates of the price equations (2) are biased because of the endogenous switching; the errors $\left(u_{i}\right)$ are not independent of whether brands are extended or not. To resolve the endogenous switching problem, the Heckman 2-step correction is typically used. ${ }^{29,30}$ However, when panel (time series and cross-sectional) data are available, the endogenous switching problem can be better resolved by separating brand-specific effects $\left(\lambda_{i}\right)$ from the errors; i.e., the remaining errors are independent of whether brands are extended or not (Heckman and Holtz, 1989). ${ }^{31}$ 
Based on a panel form of Grabowski and Vernon's (1992)10 model, the price equations were specified as below:

$$
\begin{aligned}
& p_{i t}^{E}=\alpha^{E} \cdot \text { Year }_{i t}+\beta^{E} \cdot \text { YearSinceEntry } \\
& p_{i t}^{N E}=\alpha^{N^{N E}} \cdot \lambda_{i}^{E}+v_{i t}^{E}{ }_{i t}^{E}+\beta^{N E} \cdot \text { YearSinceEntry } \\
& i t \\
& \lambda_{i}^{N E}+v_{i t}^{N E}
\end{aligned}
$$

In the panel specification, the errors $\left(u_{i t}\right)$ were decomposed into $\lambda_{i}$ and $v_{i t}$. The component $\left(\lambda_{i}\right)$ represents the effects that are specific to each individual brand such as market success, therapeutic class, and year of generic entry. The component $\left(v_{i t}\right)$ is independent of whether brands are extended or not. A fixed-effects model that estimates $\lambda_{i}$ individually treating only $v_{i t}$ as the errors gives nonbiased estimates (Wooldridge, 2000). ${ }^{32}$

The variable $p_{i t}$ is the log of a brand i's price at year $t$. The variable Year $_{i t}$ is the year when the brand i's price is taken. The variable YearSinceEntryit indicates the number of years elapsed at time $t$ since brand $i$ faced generic competition. The regression parameter of $\alpha$ thus estimates the preentry trend of annual price growth for all brands included in each equation (Figure 1). This trend will be influenced by generic entry. As time goes by, more generic competitors enter the market. As a result, the trend of annual price growth will gradually slow down postentry beginning at the time of generic entry. The parameter of $\beta$ thus measures how the postentry trend of annual price growth has changed compared with its preentry trend. If $\beta<0$, the trend of price growth has fallen $\beta \%$ per year postentry from its preentry trend; i.e., the price rigidity is rejected. If $\beta \geq 0$, the trend of price growth has gone up $\beta \%$ per year postentry from its preentry trend; i.e., the price rigidity is not rejected. SAS panel regression analyses of fixed-effect models were performed to estimate the regression parameters. One-tailed $t$ test statistics were used for the hypothesis testing (Ho: $\beta \geq 0$ ) at $\alpha=0.05$.

\section{Results}

A total of 27 brand-name drugs met the sample selection criteria. Of those, 9 brand-name drugs lost their patents in 1987, 5 in 1988, 3 in 1989, and 10 in the years 1990 to 1992 (Table 1). All the brand-name drugs are indicated for chronic diseases except for one, the antidiarrheal loperamide.

\section{Product Extension and Market Success}

The relationship between product extension and market success was examined from the set of 27 brand-name drugs selected for this study $\left(n_{1}=27\right)$. Overall, product extension was observed in 8 of the 27 brand-name drugs (30\%, Table 2). Brand-name drugs were extended more frequently when they were faced with generic entry later rather than earlier in the study period. Faced with entry of a generic competitor in 1990 or later, 7 of the 16 (44\%) brand-name drugs were extended compared with only 1 of the $11(9 \%)$ brand-name drugs extended in the period prior to 1990. Also, when line extensions were introduced, they came ahead of generic entry; i.e., approval dates of new extensions, except for one, were earlier than those of generic drugs.

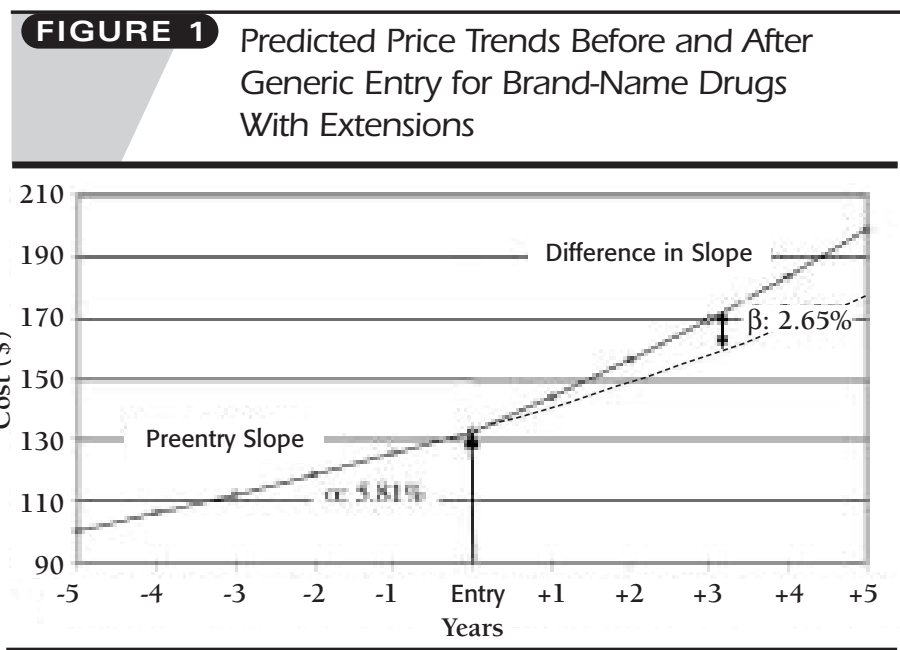

Solid line represents price trends in preentry and postentry periods. Dotted line is an extrapolation of the preentry price trend into the postentry period. Postentry, the slope of price trend increased by $2.65 \%$ per year from the preentry rate.

Notably, of 9 extensions, 4 had their formulation modified. All the formulation modifications involved extended-release or delayed-release dosage forms.

Market entries of line extensions were associated with market successes of patent-expiring brand-name drugs (Table 3). Brandname drugs that had ranked in the top 100 drugs by volume 1 year prior to the entry of generic competition had odds of extension 16 times higher than those that had not ranked in the top 100 (odds ratio $=16, P=0.02$ ). Of 9 brand-name drugs that had ranked in the top 100 drugs dispensed by volume, 6 (67\%) were extended. Of 18 brand-name drugs that had not ranked in the top 100 , only $2(11 \%)$ were extended.

\section{Product Extension and Price Rigidity}

The relationship between product extension and price rigidity was examined from a panel of drug price data; i.e., the price series for each of the 27 brand-name drugs spans 11 years $\left(n_{2}=297\right)$. On average, prices of brand-name drugs selected for this study almost doubled during the period 1985 through 1995 , from $\$ 43.50$ to $\$ 82.45$ (90\%), after controlling for inflation during the period. Each year, average prices rose between $2.37 \%$ and $10.83 \%$. Price growth was much higher in the earlier than in the later part of the period, i.e., $7.21 \%$ to 10.83\% each year between 1985 and 1992 versus about 3\% each year between 1993 and 1995.

Each brand-name drug was assigned to 1 of 2 categories: brands with new extensions and those with no new extensions. Preentry and postentry annual trends of price growth were computed individually for each brand-name drug (Table 4). Brands with no new extensions were more likely to experience a substantial postentry decline in price growth than those with extensions. Of 19 drugs with no extensions, 8 (42\%) showed a 
Product-Line Extensions and Pricing Strategies of Brand-Name Drugs Facing Patent Expiration

TABLE 1 Description of Brand-Name Drugs Selected for This Study

\begin{tabular}{|c|c|c|c|c|c|}
\hline \multirow[b]{2}{*}{ Original Brands } & \multirow[b]{2}{*}{ Presentation* } & \multirow[b]{2}{*}{ Therapeutic Category } & \multicolumn{3}{|c|}{ Generic Versions } \\
\hline & & & Name & Approval $\dagger$ & Entry丰 \\
\hline Serax & $15 \mathrm{mg} \quad 25 \mathrm{C}$ & Anxiolytics & Oxazepam & Jan. 1987 & 1988 \\
\hline Loniten & $10 \mathrm{mg} 100 \mathrm{~T}$ & Antihypertension & Minoxidil & Mar. 1987 & 1988 \\
\hline Tranxene & $7.5 \mathrm{mg} 100 \mathrm{~T}$ & Anxiolytics & Clorazepate & Jun. 1987 & 1988 \\
\hline Norpramin & $25 \mathrm{mg} 100 \mathrm{~T}$ & Antidepressants & Desipramine & Jun. 1987 & 1988 \\
\hline Navane & $1 \mathrm{mg} 100 \mathrm{C}$ & Tranquilizers & Thiothixene & Jun. 1987 & 1988 \\
\hline Trilafon & $8 \mathrm{mg} 100 \mathrm{~T}$ & Tranquilizers & Perphenazine & Sep. 1987 & 1988 \\
\hline Centrax & $10 \mathrm{mg} 100 \mathrm{C}$ & Anxiolytics & Prazepam§ & Nov. 1987 & 1988 \\
\hline Ludiomil & $25 \mathrm{mg} 100 \mathrm{~T}$ & Antidepression & Maprotiline & Dec. 1987 & 1989 \\
\hline Surmontil & $25 \mathrm{mg} 100 \mathrm{C}$ & Antidepression & Trimipramine & Dec. 1987 & 1988 \\
\hline Lioresal & $10 \mathrm{mg} 100 \mathrm{~T}$ & Muscle relaxants & Baclofen & May 1988 & 1990 \\
\hline Nalfon & $300 \mathrm{mg} 100 \mathrm{C}$ & NSAID & Fenoprofen & May 1988 & 1989 \\
\hline Loxitane & $10 \mathrm{mg} 100 \mathrm{C}$ & Tranquilizers & Loxapine & Jun. 1988 & 1989 \\
\hline Tenormin & $50 \mathrm{mg} 100 \mathrm{~T}$ & Antihypertension & Atenolol & Jul. 1988 & 1992 \\
\hline Minipress & $1 \mathrm{mg} 250 \mathrm{C}$ & Antihypertension & Prazosin & Sep. 1988 & 1990 \\
\hline Blocadren & $10 \mathrm{mg} 100 \mathrm{~T}$ & Antihypertension & Timolol & Apr. 1989 & 1990 \\
\hline Asendin & $50 \mathrm{mg} 100 \mathrm{~T}$ & Antidepression & Amoxapine & May 1989 & 1990 \\
\hline Flexeril & $10 \mathrm{mg} 100 \mathrm{~T}$ & Muscle telaxants & Cyclobenzaprine & May 1989 & 1990 \\
\hline Procardia & $10 \mathrm{mg} 100 \mathrm{C}$ & Antihypertension & Nifedipine & Jul. 1990 & 1991 \\
\hline Imodium & $2 \mathrm{mg} 100 \mathrm{C}$ & Antidiarrhea & Loperamide & Aug. 1991 & 1992 \\
\hline Tolectin & $400 \mathrm{mg} 100 \mathrm{C}$ & NSAID & Tolmetin & Nov. 1991 & 1992 \\
\hline Tavist & $2.68 \mathrm{mg} 100 \mathrm{~T}$ & Antihistamine & Clemastine & Jan. 1992 & 1993 \\
\hline Cardizem & $30 \mathrm{mg} 100 \mathrm{~T}$ & Antihypertension & Diltiazem & Mar. 1992 & 1993 \\
\hline Pamelor & $25 \mathrm{mg} 100 \mathrm{C}$ & Antidepression & Nortriptyline & Mar. 1992 & 1993 \\
\hline Feldene & $20 \mathrm{mg} 100 \mathrm{C}$ & NSAID & Piroxicam & May 1992 & 1993 \\
\hline Dolobid & $250 \mathrm{mg} \quad 60 \mathrm{~T}$ & NSAID & Diflunisal & Jul. 1992 & 1993 \\
\hline Visken & $5 \mathrm{mg} 100 \mathrm{~T}$ & Antihypertension & Pindolol & Sep. 1992 & 1993 \\
\hline Naprosyn & $250 \mathrm{mg} 100 \mathrm{~T}$ & NSAID & Naproxen & Oct. 1992 & 1994 \\
\hline
\end{tabular}

* $C=$ capsule; $T=$ tablet.

+ Approval dates are listed in the FDA Orange Book.

\# Entry indicates the year in which annual publications of Drug Topics Red Book first lists a generic version.

$\S$ The drug product was discontinued by the manufacturer in 1996.

NSAID $=$ nonsteroidal anti-inflammatory drug.

decline of more than $6 \%$ per year postentry. In contrast, of the 8 brands with extensions, only 1 (13\%) experienced a price decline of as much. When annual trends of price growth were averaged over each category of brand-name drugs, those without extensions fell as much as $3.78 \%$ per year postentry. However, those with extensions fell less than $1 \%$ per year postentry. Notably, those with formulation extensions did not fall but, instead, gained $0.78 \%$ per year postentry.

Fixed-effects panel regressions were performed first for all brand-name drugs combined and then separately for each category of brands, i.e., those with no line extensions and those with line extensions (Table 5). On average, all brandname drugs combined had a price increase of $7.49 \%$ per year during the preentry period $(P<0.001)$ (Table 5). Postentry, the trend continued with little change; though a small decline occurred, it was not statistically significant $(\beta=-0.86 \%$, $P=0.21$ ). In other words, the hypothesis of price rigidity was not rejected in all brand-name drugs combined. However, when examined separately for each category of brands, the price rigidity was rejected in brands with no extensions ( $\beta=-2.40 \%$, $P<0.001)$ but not in those with extensions $(\beta=2.65 \%$, $P<0.033)$. 
TABLE 2 Original Brand-Name Drugs, Generic Drugs, and New Extensions

\begin{tabular}{|c|c|c|c|c|c|}
\hline Brand Name & $\begin{array}{c}\text { Original Brands } \\
\text { Class }\end{array}$ & Generic Approval & Type & $\begin{array}{l}\text { New Extensions } \\
\text { Difference }\end{array}$ & Approval Date \\
\hline \multirow[t]{2}{*}{ Naprosyn } & COX inhibitor & Oct. 1992 & Molecule & COX inhibitor & Dec. 1991* \\
\hline & & & Formulation & Delayed release & Oct. 1994 \\
\hline Visken & Beta-blocker & Sep. 1992 & Molecule & Calcium channel blocker & Dec. 1990 \\
\hline \multirow[t]{3}{*}{ Cardizem } & Calcium channel blocker & Mar. 1992 & Formulation & Twice-a-day dosage & Jan. 1989 \\
\hline & & & Formulation & Once-a-day dosage & Dec. 1991 \\
\hline & & & Molecule & ACE inhibitor & Jan. 1991 \\
\hline \multirow[t]{2}{*}{ Procardia } & Calcium channel blocker & Jul. 1990 & Formulation & Extended release & Sep. 1989 \\
\hline & & & Molecule & Calcium channel blocker & Jul. 1992 \\
\hline \multirow[t]{3}{*}{ Blocadren } & Beta-blocker & Apr. 1989 & Molecule & ACE inhibitor & Dec. 1985 \\
\hline & & & Molecule & ACE inhibitor & Dec. 1987 \\
\hline & & & Molecule & ACE II inhibitor & Apr. 1994 \\
\hline \multirow[t]{2}{*}{ Minipress } & Alpha-agonist & Sep. 1988 & Molecule & Alpha-agonist & Nov. 1990 \\
\hline & & & Formulation $\dagger$ & Extended release & Jan. 1992 \\
\hline Tenormin & Beta-blocker & Jul. 1988 & Molecule & ACE inhibitor & May 1988 \\
\hline Tranxene & Benzodiazepine & Jun. 1987 & Molecule & Benzodiazepine & Dec. 1990 \\
\hline
\end{tabular}

* The approval date is for the tablet form; the injectable form was approved in November 1989.

$\dagger$ Approved but never marketed in the U.S. as Minipress XL.

$A C E=$ angiotensin-converting enzyme; $C O X=$ cyclooxygenase.

\section{Discussion}

Price rigidity existed in the set of 27 drug brands selected for this study. This finding coincides with previous studies., ${ }^{7,0,33}$ However, further analyses added more understanding of the price rigidity. When the price rigidity was separately examined for the 2 categories of brand-name drugs, price rigidity existed in drugs with extensions but not in drugs with no extensions. In other words, it was line extensions that helped the original brands remain price insensitive to generic entry. This finding is consistent with the findings of Kadiyali et al., that a line extension makes its original product less elastic to changes in its rival product's price. ${ }^{15}$

Traditionally, brand loyalty is the only explanation for the price rigidity of patent-expired brand-name drugs to generic drug entry. According to the brand-loyalty explanation, patentexpired brand-name drugs have price rigidity because a sufficient number of price-insensitive customers continue to buy brandname drugs despite the availability of affordable generic versions. ${ }^{5,7,10}$ However, the price rivalry between brand-name drugs and their generic versions has increased substantially since the passage of the 1984 law. The penetration of generic drugs in the total pharmaceutical market has steadily increased since the drug legislation, from $19 \%$ to $42 \%$ of all prescriptions dispensed with generic drugs. ${ }^{34,35}$ When prescriptions written for single-source brand-name drugs that do not have generic versions are excluded, more than $92 \%$ of the prescriptions are

\begin{tabular}{l|c|c|c|c|c}
\hline TABLE 3 & $\begin{array}{l}\text { Logistic Regression Analysis of the } \\
\text { Relationship Between Market Entry } \\
\text { of Extensions and Market Success } \\
\text { of Original Brand-Name Drugs. }{ }^{*}\end{array}$ \\
\hline Variable & Estimate & SE & Pr> $\chi^{2}$ & $\begin{array}{c}\text { Odds } \\
\text { Ratio }\end{array}$ & $95 \%$ CI \\
\hline Intercept & -2.08 & 0.75 & 0.006 & & \\
Top $100 \dagger$ & 2.77 & 1.03 & 0.007 & 16.00 & $2.12-120.65$ \\
\hline
\end{tabular}

* Number of brand-name drugs is 27.

† Indicates whether the brand is in the top 100 drugs most frequently dispensed. $\mathrm{CI}=$ confidence interval.

dispensed with a generic drug. ${ }^{14}$ In other words, the number of price-sensitive consumers has increased over the years, which challenges the brand-loyalty explanation.

The findings of this study suggest that price rigidity can arise even when a prescription drug market consists primarily of price-sensitive consumers. An original brand is closely related to its generic version as well as to its extension, and thus the demand for the generic as well as for the extension will be elastic to changes in the prices of the original in a price-sensitive market. Since the extension has the market exclusivity the original brand has just lost, and its demand is elastic to changes in the 


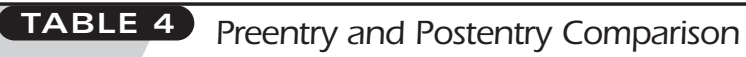 of Annual Price Increases of Original Brands by Category}

\begin{tabular}{|c|c|c|c|}
\hline \multirow[b]{2}{*}{ Drug Name } & \multicolumn{2}{|c|}{$\begin{array}{l}\text { Annual Price } \\
\text { Increases (\%) }\end{array}$} & \multirow{2}{*}{$\begin{array}{l}\text { Difference } \\
\quad( \pm)\end{array}$} \\
\hline & Preentry & Postentry & \\
\hline \multicolumn{4}{|c|}{ Brands with no extensions } \\
\hline Fenoprofen $300 \mathrm{mg}$ & 10.58 & 0.53 & -10.05 \\
\hline Cyclobenzaprine $10 \mathrm{mg}$ & 11.29 & 1.56 & -9.73 \\
\hline Diflunisal $250 \mathrm{mg}$ & 4.64 & 2.00 & -2.64 \\
\hline Minoxidil $10 \mathrm{mg}$ & 7.44 & 3.15 & -4.29 \\
\hline Baclofen $10 \mathrm{mg}$ & 2.23 & 3.36 & +1.13 \\
\hline Maprotiline $25 \mathrm{mg}$ & 9.98 & 3.52 & -6.46 \\
\hline Piroxicam $20 \mathrm{mg}$ & 5.94 & 4.70 & -1.24 \\
\hline Loperamide $2 \mathrm{mg}$ & 5.28 & 4.71 & -0.57 \\
\hline Tolmetin $400 \mathrm{mg}$ & 8.07 & 5.42 & -2.65 \\
\hline Thiothixene $1 \mathrm{mg}$ & 7.23 & 6.84 & -0.39 \\
\hline Clemastine $2.68 \mathrm{mg}$ & 14.07 & 7.26 & -6.81 \\
\hline Perphenazine $8 \mathrm{mg}$ & 12.39 & 7.48 & -4.91 \\
\hline Oxazepam $15 \mathrm{mg}$ & 25.76 & 7.49 & -18.27 \\
\hline Loxapine $10 \mathrm{mg}$ & 9.98 & 8.24 & -1.74 \\
\hline Trimipramine $25 \mathrm{mg}$ & 23.11 & 8.53 & -14.58 \\
\hline Amoxapine $50 \mathrm{mg}$ & 14.93 & 8.61 & -6.32 \\
\hline Nortriptyline $25 \mathrm{mg}$ & 16.18 & 8.76 & -7.42 \\
\hline Prazepam $10 \mathrm{mg}$ & 13.49 & 9.76 & -3.73 \\
\hline Desipramine $25 \mathrm{mg}$ & 5.47 & 10.41 & 4.94 \\
\hline Subtotal & 9.88 & 6.10 & -3.78 \\
\hline \multicolumn{4}{|l|}{ Brands with extensions } \\
\hline Naproxen 250 mg* & 2.84 & 2.29 & -0.55 \\
\hline Timolol $10 \mathrm{mg}$ & 7.71 & 2.45 & -5.26 \\
\hline Diltiazem $30 \mathrm{mg} *$ & 4.01 & 4.42 & +0.41 \\
\hline Atenolol $50 \mathrm{mg}$ & 6.35 & 4.77 & -1.58 \\
\hline Prazosin 1 mg* & 8.02 & 6.39 & -1.63 \\
\hline Nifedipine $10 \mathrm{mg} *$ & 6.10 & 6.44 & +0.34 \\
\hline Pindolol $5 \mathrm{mg}$ & 16.86 & 6.60 & -10.26 \\
\hline Clorazepate $7.5 \mathrm{mg}$ & 19.28 & 13.94 & -5.34 \\
\hline Subtotal & 7.65 & 6.68 & -0.97 \\
\hline
\end{tabular}

* Brands that had their formulation changed. For these cases, the average postentry price increase was $5.40 \%$ per year, up $0.78 \%$ per year from the preentry.

original's price, the brand owner would change the original's price to support the demand for the extension. Thus, the original's price would become rigid with the entry of generic versions but would be sensitive to the entry of extensions. The present study has not examined the relationship between the original brand's price and the demand for the line extension. However, it does show that the price of the original brand is rigid to the entry of generic versions when extended, but not when not extended.

Two types of extensions were identified in this study, one due to a change in formulation (such as from immediate release to extended release) and the other due to a change in the molecule (such as from prazosin to doxazosin). A formulation extension is more closely related to its original brand than an extension created by a change in the molecule; thus its demand would be more elastic to changes in the prices of the original. As a result, the price of the original would be less likely to change with generic entry when the extension is a formulation type compared with a molecule type. According to the study results, price trends of original brands, on average, went up $0.78 \%$ per year postentry with formulation modification, while they went down $0.97 \%$ per year with all types of extensions (Table 4 ).

Product-line extensions propel examination of public policy issues amid concerns about rising prescription drug expenditures. Cardizem CD (diltiazem) made more than $\$ 735$ million in retail sales during the 12 months ending May 31, 1999. ${ }^{36}$ Procardia XL (nifedipine) had sales of $\$ 299.7$ million during the 12 months ending October 31, 2000. ${ }^{37}$ For these line extensions of calcium channel blockers, drug spending was greater than $\$ 1$ billion per year despite the fact that generic versions of the original form had been available since 1992 for Cardizem and since 1990 for Procardia.

Wellbutrin (bupropion) is a more recent example. The XL (once-daily) form of the drug was ranked 35th (\$949 million) in sales in community pharmacy in 2004, and the SR (twicedaily) form was ranked 63rd ( $\$ 529$ million); the combined sales of these extended-release versions ( $\$ 1.5$ billion) ranked this drug in the top 20 drugs by sales dollars in 2004 despite the availability of generic versions of the original form ( 3 times daily) since late in $1999 .{ }^{38}$

The cost advantage of using generic versions is substantial. The AWP was $\$ 120$ for Cardizem CD and $\$ 150$ for Procardia $\mathrm{XL}$. However, generic versions of Cardizem and Procardia cost about $\$ 24$ and $\$ 27$, respectively, for the equivalent number of days of therapy. ${ }^{24}$ The majority of the drug spending for the diltiazem and nifedipine molecules could have been avoided if generic versions were used in lieu of expensive new extensions.

The results of this study may motivate researchers to examine factors that help extensions fend off the otherwise competitive price rivalry from generic drugs. Some supply-side characteristics, for example, may hinder generic drug firms from introducing their own versions of extensions. In fact, generic drug firms have faced barriers to developing the continuous-release dosage form, a popular form of product-line extension. ${ }^{39}$ In the past, only a few generic drug firms had the resources necessary to develop continuous-release dosage forms.

Some demand-side factors may also encourage brand-name companies to use their extension products to fend off generic competition. Dispensing a generic version for a prescription 
written for the original brand is called generic substitution; this practice is promoted by health plans and pharmacy benefit managers and is encouraged by state laws adopted in recent years. The Texas regulations are representative of the nationwide trend to encourage generic substitution and, effective June 1, 2002, required physicians to specifically block generic substitution using specific hand-written language, "brand necessary" or "brand medically necessary." in 2002 and consequent regulations went further in making generic drugs more readily available to Texas residents by not requiring pharmacists to inform physicians that a "brandnecessary" prescription does not conform to the new rules and that a generic drug will be dispensed.

However, dispensing a generic version of the original brand for a prescription written for the line extension of the original brand extension is called therapeutic substitution or therapeutic selection and is not yet widely facilitated by state law and regulation..$^{41}$ In this market environment, the owner of the brand is able to shift demand from the original brand to the line extension by promotion of the line extension brand to physicians, including the use of product sampling to physicians. ${ }^{42}$

\section{Limitations}

The present study used AWPs for empirical analyses. The AWPs are obtained through surveys of manufacturers, distributors, and other suppliers. ${ }^{24}$ AWPs differ from the actual prices that buyers pay at transaction because they do not account for rebates, charge-backs, and discounts that may occur and are, therefore, not the purchase prices paid by pharmacies or thirdparty payers. However, AWPs are relevant and important because pharmacy reimbursement is most commonly based on discounts from AWP for brand-name drugs, the principal economic focus of the present study.

Other strategic behaviors may influence pricing decisions for original brand-name drugs. For example, comarketing, the switch from prescription to over-the-counter status, and the phenomenon of brand-name pharmaceutical manufacturers increasingly engaging in ownership of generic drug production may have some bearing on the prices of brand-name drugs, including product-line extensions. Future studies need to sort out these influences.

Factors other than the market success of original brands before facing generic entry may influence the market entry of extensions. For some drugs, it is easier to produce a line extension. For others, it may not be feasible to develop an extension because of clinical, scientific, or economic factors. Future studies need to examine those factors that may influence the market entry of product-line extensions.

Also, from another perspective, the original brand-loyalty hypothesis is not inconsistent with these study findings. Products are only extended if they are successful in the market (e.g., in the top 100 drugs by sales revenue). Successful brand-

\begin{tabular}{|c|c|c|c|}
\hline \multirow[b]{2}{*}{ Variable } & \multirow[b]{2}{*}{$\begin{array}{l}\text { All Original } \\
\text { Brands }\end{array}$} & \multicolumn{2}{|c|}{ Category of Original Brands } \\
\hline & & $\begin{array}{l}\text { Brands With } \\
\text { No Extensions }\end{array}$ & $\begin{array}{c}\text { Brands With } \\
\text { Extensions }\end{array}$ \\
\hline Year & $\begin{array}{l}0.0749 \dagger \\
(16.40)\end{array}$ & $\begin{array}{c}0.0849 \dagger \\
(15.23)\end{array}$ & $\begin{array}{c}0.0581 \dagger \\
(7.38)\end{array}$ \\
\hline YearSinceEntry & $\begin{array}{l}-0.0086 \\
(-1.26)\end{array}$ & $\begin{array}{c}-0.0240 \dagger \\
(-3.04)\end{array}$ & $\begin{array}{c}0.0265 \neq \\
(1.86)\end{array}$ \\
\hline$\overline{\mathrm{R}^{2}}$ & 0.9478 & 0.9618 & 0.8871 \\
\hline$\overline{\mathrm{N}}$ & 297 & 209 & 88 \\
\hline \multicolumn{4}{|c|}{$\begin{array}{l}\text { * Numbers are } \beta \text { estimates with } t \text { values in parentheses. Individual brand-specifi } \\
\text { estimates are omitted in the table for simplicity. } \\
+P<0.01 \text { based on } 1 \text {-tailed t test. } \\
\neq P<0.05 \text {, based on } 1 \text {-tailed } t \text { test. }\end{array}$} \\
\hline
\end{tabular}

name products command brand loyalty and can price-discriminate against loyal customers. Less-successful products (e.g., not in the top 100 by sales) are already known to have less market support and/or brand loyalty and thus have less brand value to support through price discrimination or price rigidity.

The present study used the number of prescriptions dispensed as a proxy for market success. Although prescription volume is one element of profit, market success is better measured by sales revenue or by profit (sales revenue minus production and other operating costs). Since production costs and other operating costs are difficult to estimate because of their confidential nature, the present study used prescription volume as a proxy for market success. We also did not investigate the effect on our results of using the top 100 drugs in community pharmacy ranked by sales revenue rather than by dispensing prescription volume.

\section{Conclusion}

This study provides an alternative explanation for the continued price rigidity of patent-expired brand-name drugs despite the increased market entries of generic competitors facilitated by the 1984 drug price and patent law. According to this alternative explanation, the price rigidity results from product-line extensions that brand-name drug firms introduce for their patent-expiring brand-name drugs. This study provided some support for this alternative explanation using a set of orally administered, single pharmaceutical ingredient, original brandname drugs that had lost their patents between 1987 and 1992.

The marketing strategy of extending the original drug brands facing generic drug competition has important policy implications. Product-line extensions thwart generic competition and inherit the market success of the original brand, sometimes with little quality improvement over the original brand. With 
prescription drug expenditures rising faster than the expenditures for other goods and services in the general as well as in the medical economy, the marketing strategy of using product-line extensions is of interest from a policy perspective and of interest in the cost-effective administration of pharmacy benefits.

\section{DISCLOSURES}

No outside funding supported this study. The authors disclose no potential bias or conflict of interest relating to this article. Author Song Hee Hong served as principal author of the study. Study concept and design were contributed primarily by Hong, with input from authors Marvin D. Shepherd and David Scoones. Data collection was the work of Shepherd and Hong, with contributions from Scoones and author Thomas T.H. Wan; data interpretation was the work of all authors. Drafting of the manuscript and its critical revision was primarily the work of Hong and Wan, with input from the coauthors.

\section{REFERENCES}

1. Levit K, Smith C, Cowan C, Lazenby H, Sensenig A, Catlin A. Trends in U.S. health care spending, 2001. Health Aff. 2003;22:154-64.

2. Levit K, Smith C, Cowan C, Sensenig A, Catlin A. Health spending rebound continues in 2002. Health Aff. 2004;23:147-59.

3. Henry J. Kaiser Family Foundation. Trends and Indicators in the Changing Health Care Marketplace Chartbook. Section 1: Health Spending and Costs, Including Prescription Drugs. Menlo Park, CA: Henry J. Kaiser Family Foundation. Publication no. 7031; updated July 20, 2005

4. McGinley L. Drug study finds little innovation. Wall Street Journal. May 29, 2002:A3

5. Frank RG, Salkever DS. Generic entry and the pricing of pharmaceuticals. J Econ Manage Strategy. 1997;6(1):75-90.

6. Statman M, Tyebjee TT. Trademarks, patents, and innovation in the ethical drug industry. J Mark. 1981;35(2):529-47.

7. Frank RG, Salkever DS. Pricing, patent loss and the market for pharmaceuticals. South Econ J. 1992;59(2):165-79.

8. Price Competition and Patent Term Restoration Act of 1984. Pub. L. No. 98-417, 98 Stat. 1585 (1984)

9. Olson MK. Political influence and regulatory policy: the 1984 drug legislation. Econ Inquiry. 1994;32(3):363-82

10. Grabowski HG, Vernon JM. Brand loyalty, entry, and price competition in pharmaceuticals after the 1984 drug act. J Law Econ. 1992;35(2):331-50.

11. Statman M. The effect of patent expiration on the market position of drugs. In: Helms R, ed. Drugs and Health. Washington, D.C.: American Enterprise Institute; 1981:140-51.

12. Scherer FM. Pricing, profits, and technological progress in the pharmaceutical industry. J Econ Perspect. 1993;7(3):97-115.

13. Cook A, Acton JP, Schwartz E. Congressional Budget Office. How Increased Competition from Generic Drugs Has Affected Prices and Returns in the Pharmaceutical Industry [executive summary]. Washington, DC: Congressional Budget Office; July 1998.

14. Wosinka M, Huckman RS. Generic dispensing and substitution in mail and retail pharmacies [Web exclusive]. Health Aff. 2004;July 28;W4:409-16

15. Kadiyali V, Vilcassim NJ, Chintagunta PK. Product line extensions and competitive market interactions: an empirical analysis. J Econometrics. 1998;89(1-2):339-63.

16. Desai KK, Keller KL. The effects of ingredient branding strategies on host brand extendibility. J Mark. 2002;66(6):73-93.

17. Peny JM, Young R. Are generic defense strategies worth the effort? Scrip magazine. Richmond, Surrey, UK: PJB Publications Ltd.; 1996:28-34.

18. NIHCM Foundation. Changing patterns of pharmaceutical innovation.

Washington, D.C.: National Institute for Health Care Management; May 2002.
19. Schmalensee R. Entry deterrence in the ready-to-eat breakfast cereal industry. Rand J Econ. 1978;9(2):305-27.

20. Judd K. Credible spatial preemption. Rand J Econ. 1985;16:153-66.

21. Kadiyali V, Vilcassim NJ, Chintagunta PK. Empirical analysis of competitive product line pricing decisions: lead, follow, or move together? J Bus. 1996; 69(4):459-87.

22. First DataBank. Drug NDC File. San Bruno, CA: The Hearst Corporation; 1996.

23. U.S. Food and Drug Administration, Center for Drug Evaluation and Research. Orange Book Products 96/10. 1996. Available at: www.fda.gov/ cder/orange/default.htm. Accessed October 27, 2005.

24. Drug Topics Red Book. Montvale, NJ: Medical Economics Company; 2001.

25. First DataBank. First DataBank Hierarchical Ingredient Code List Technical Manual. San Bruno, CA: The Hearst Corporation; 1989.

26. Top 200 Drugs. Am Druggist. 1995;211:20-24.

27. U.S. Department of Health \& Human Services, Office of the Inspector General. Medicaid Pharmacy_Actual Acquisition Cost of Brand Name Prescription Drug Products. Washington, DC: DHHS OIG; August 2001. (A-06-00-00023).

28. U.S. Department of Commerce: Bureau of Economic Analysis. Gross Domestic Product: Implicit Price Deflator. Washington, DC: U.S. Department of Commerce; 2003.

29. Maddala GS. Limited-Dependent and Qualitative Variables in Econometrics. Cambridge, U.K.: Cambridge University Press; 1983.

30. Heckman JJ. Sample selection bias as a specification error. Econometrica. 1979;47(1):153-61.

31. Heckman JJ, Holtz VJ. Choosing among alternative nonexperimental methods for estimating the impact of social programs: the case of manpower training. J Am Stat Assoc. 1989;84(408):862-74.

32. Wooldridge JM. Introductory Econometrics: A Modern Approach. Mason, OH: South-Western College Publishing; 2000.

33. Grabowski HG, Vernon JM. Longer patents for increased generic competition in the US. PharmacoEconomics. 1996;10(suppl 2):110-23.

34. Colchamiro R. Generic drugs: the patent wars rage on. Am Druggist. 1999;216:33-42.

35. Schacht WH, Thomas JR. Patent law and its application to the pharmaceutical industry: an examination of the drug price competition and Patent Term Restoration Act of 1984. Congressional Research Service report; updated December 18, 2000. Available at: http://www.law.umaryland.edu/marshall/ crsreports/crsdocuments/RL30756.pdf. Accessed October 27, 2005.

36. The Cardizem CD case: how generic substitution poses revenue questions. Med Mark Media. 2000;35(2]);24.

37. FDA approves Biovail's generic procardia XL $30 \mathrm{mg}$. Worldwide Biotech. March 1, 2001. Available at: http://www.findarticles.com/p/articles/mi_ m0DHC/is_3_13/ai_70735272. Accessed October 27, 2005.

38. Top 200 brand-name drugs by retail dollars in 2004. Drug Top. 18. 2-212005. Available at: http://www.drugtopics.com/drugtopics/data/articlestandard/ drugtopics/112005/150644/article.pdf. Accessed October 27, 2005.

39. Farmer KC, Gambir AK. Acquisition value factors for U.S. pharmaceutical firms in a merger environment. J Res Pharm Econ. 1993;5(2):37-57.

40. Texas Statutes: Occupation Code, Chapter 562, section 562.015. Available at: http://www.capitol.state.tx.us/statutes/octoc.html. Accessed October 25, 2005.

41. Generic and Therapeutic Substitution. Natl Pharm Compliance News. 4th quarter. Mount Prospect, IL: National Association of Boards of Pharmacy; 2000. Available at: http://www.nabp.net/ftpfiles/newsletters/ nationalnews/4thquarternews2000.pdf. Accessed April 15, 2005.

42. Chew LD, O’Young TS, Hazlet TK, Bradley KA, Maynard C, Lessler DS. A physician survey of the effect of drug sample availability on physicians' behavior. J Gen Intern Med. 2000;15(7):478-83. 